\title{
The Innovation and Perfection of Chinese Enterprise Form
}

\author{
Nannan Qu \\ Shandong University of Finance and Economics, Jinan, China \\ Email: qunannanfx@163.com
}

Received 23 July 2015; accepted 15 August 2015; published 18 August 2015

Copyright (C 2015 by author and Scientific Research Publishing Inc.

This work is licensed under the Creative Commons Attribution International License (CC BY).

http://creativecommons.org/licenses/by/4.0/

C) (i) Open Access

\begin{abstract}
China's enterprise form adopts legal principle, lack of flexibility and innovation, which restricts the development of China's economy. The latest revision of the company law has abolished the restriction of registered capital and loosened of market access, and has brought the opportunity and challenge to the innovation and perfection of enterprise form. This paper mainly discusses the value of the guarantee of Limited Liability Company based on the foreign experience to innovate and perfect our country's enterprise form, and to better promote the development of the socialist market economy.
\end{abstract}

\section{Keywords}

Enterprise Form, Innovation, Perfection, Guarantee Limited Liability Company

\section{Introduction}

The latest revision of China's "company law" has abolished the restriction of registered capital and loosened of market access. This change shows that China gradually carried out the reform of enterprises to promote economic development full of energy. And the innovation of enterprise form is the problem that we must consider and pay attention to, because the form of the enterprise has very important influence to the development of the enterprise; the innovation and perfection of the form of enterprise can better promote the development of our country's socialist market economy. This paper focuses on discussion the enlightenment of one foreign enterprise form-Guarantee Limited Liability Company to China; it has important reference significance to the innovation and perfection of China's enterprise form.

\section{The Meaning, Types and Characteristics of Chinese Enterprise Forms}

\subsection{The Meaning of Chinese Enterprise Forms}

Enterprise form is the manifestation of the enterprise. It can be divided into different categories according to

How to cite this paper: Qu, N.N. (2015) The Innovation and Perfection of Chinese Enterprise Form. Open Journal of Social Sciences, 3, 69-71. http://dx.doi.org/10.4236/jss.2015.38007 
different standards. There are two standards for the determination of the corporate form, which are the academic standards and the legal standards. Academic standards are the theoretical interpretation and classification according to the objective situation of enterprises and the legal standards of the scholars that study the enterprise and enterprise law. This classification is not binding and mandatory in legal, but the interpretation of the theory has a guide and reference to the development and implementation of enterprise law. The legal standard is the type of enterprise which is confirmed and classified according to the provisions of the enterprise law. Legally enterprise forms are binding and compulsory. However, the specific content and the procedural requirements of different forms of enterprises are also very different because of the different forms of enterprises.

\subsection{The Types of Chinese Enterprise Forms}

Our country's existing enterprise forms mainly include: Limited Liability Company, a company limited by shares, sole proprietorship enterprises, partnership enterprises (ordinary partnership, special general partnership, limited partnership, joint-stock cooperative enterprises, Sino-foreign joint ventures, Sino-foreign cooperative enterprises, wholly foreign owned enterprise, farmers' professional co-operatives, collective enterprises, etc, in terms of enterprise form, our country strictly adopts "enterprise forms use legal principle” (Xu Qiangsheng, 2010) [1]. Enterprise form can be divided into different categories according to different standards. It can be divided into the following forms: 1) with the investor's investment way and the form of responsibility: individual proprietorship enterprise, partnership enterprise, corporate enterprise; 2) with the different regions of the investors: domestic enterprises, foreign enterprises and Hong Kong, Macao, Taiwan investment enterprises; 3) by ownership structure: ownership enterprises, collective ownership and private enterprises and foreign investment; 4) according to the different responsible of shareholders of the company: Unlimited Company, limited liability company; 5) according to the credit: people companies, investment companies, people and investment companies; 6) by scale: jumbo enterprises, large enterprises, medium-sized enterprises, small enterprises and micro enterprises.

\subsection{The Characteristics of Chinese Enterprise Forms}

This kind of enterprise form in our country is lack of flexibility and innovation in the contemporary realistic society, which can not meet the needs of new economic forms such as knowledge economy, venture capital and so on. The diversification of the legal form of enterprise is the inevitable demand of economic development, but at present, the legal form of our country is relatively simple and rough. The scarcity of legal form of enterprise means the freedom of choice of investors is limited, the variety of investment demand of different investors can not be met because of the difference of the form of capital, the amount and investment, the incentives of investment is insufficient, economic development will certainly be affected (Cao Xingquan \& Yang Jiahong, 2002) [2].

\section{The Innovation of Chinese Enterprise Forms}

China's latest revision of "Company Law" cancel the constraints of registered capital, access to the relaxation of market players, it has a positive effect on investment incentives, encourage entrepreneurship and to promote the development of socialist market economy. But in our country lack of a credit system, how to better protect the interests of creditors is a problem worthy of our thinking (Li Yingxue, 2014) [3]. We can innovate from the angle of the enterprise forms, learn from foreign experience to perfect our country's enterprise form, in order to promote the better development of our economy. A form of enterprise which is originated from the legislation of the British company_-Guarantee Limited Liability company, it can be used for reference in our country.

Guarantee Limited Liability Company is a special form of the company, also known as supplementary liability company. From the perspective of corporate form, it can be understood as a form of a company between the form of a limited liability company and an unlimited company. The limited liability companies are the shareholders take responsibility no more than the amount of investment and an unlimited company is the shareholders take joint responsibility with their total assets to the company's debt. But Guarantee Limited Liability Company is neither to limit the amount of investment to assume responsibility nor to assume unlimited liability. It undertakes supplementary liability with a promised surety. So it is between the types of limited and unlimited companies, and it is an intermediate form of company (Qin Fangju, 2011) [4]. Guarantee Limited Liability Company shall formulate the articles of association, and record the amount of the guarantee. In the articles of association of the company, the shareholders should be defined as the limit and the detailed information of the shareholders, 
and in the name of the company, the words of the limited liability companies should be stated, which is convenient for the relative identification. From the point of view of the bond guarantee, the guarantee of the limited liability company is a special kind of people's insurance. From the contract law of the guarantee system of the debt to the enterprise law of the different responsibility of the investors in the corporate debt obligations, all hope to ensure the performance of the debt. Limited liability companies can be understood as a special form of guarantee, provided guarantee by the company's shareholders to the company's debt, but this guarantee is different from the traditional guarantee contract. In the traditional guarantee contract, generally provide assurance by third people.

\section{The Perfection of Enterprise Form in Our Country}

Although countries adopts the Guarantee Limited Liability Company in the world are less, but its value is worth our attention. First of all, it can enrich the types of company. The types of Companies in our country are not perfect. There are only two types of companies in our country, which are limited liability companies and company limited by shares (Dou Jingwei, 2014) [5]. These two types of companies are Capital Company, lack of the provisions of the personal company, but in the modern society, the personal company also has its own space to adopt. Guarantee Limited Liability Company not only has a certain amount of people, but also has the limited responsibility. Therefore, there should be a space for its function. Second, Guarantee Limited Liability Company can ensure the realization of creditor's rights. Guarantee Limited Liability Company's shareholders provide a certain degree of security outside investment by their personal property for the company's debt, which effectively expanded the scope of responsible property of the company. In the value of the system, similar to the company personality denial system, their purpose is to guarantee the realization of the creditors' rights.

The Guarantee Limited Liability Company still has some limitations although has the advantages. This is mainly reflected in the shareholders bear some responsibility to the debts of the company with personal property, which actually improve the shareholders' investment cost, and the shareholders may need to make up for the companies' loss with the personal property. At the same time, the Guarantee Limited Liability Company needs to bear a certain responsibility for security for the company's debt based on the shareholders' investment, making the company's legal relations becomes more complex, prone to emerge disputes. In this case, the motivation to establish Limited Liability Company becomes loss. Between the Limited Liability Company and Guarantee Limited Liability Company, shareholders would no doubt prefer to choose the former because its responsibility for nothing, lower risk and simple relationship. But this is not enough to become a reason to oppose the establishment of a limited liability company, as long as there is a need to exist, then the legislator should not be ignored. At the same time in specific areas involving human capital investment, the Guarantee Limited Liability Company still has the competitive advantage. So we can consider adopting this form of company in the company law or separate legislation, and force the investor to set up the form of the company on some occasions, to innovate and perfect our country's enterprise forms.

\section{Conclusion}

The enterprise form of our country is not perfect; it needs to be innovated and perfected in the process of development in order to meet the requirements of economic development. The Guarantee Limited Liability Company can rich the company form in our company and protect the achievement of creditor. But it also has its own limitations. We should recognize the existence value of Guarantee Limited Liability Company. We can draw lessons from this enterprise form in combination with the characteristics and requirements of the economic development of our country, rather than mechanically.

\section{References}

[1] Xu, Q.S. (2010) Study on the Legal Principle of Enterprise Forms. The Development of Legal and Social, 1.

[2] Cao, X.Q. and Yang, J.H. (2002) The Differentiation Design of Enterprise Legal Form. Modern Law, 10.

[3] Li, Y.X. (2014) The Thinking Causing by the Minimum Registered Capital of the Company Law in the Mainland. Chinese Journal, 11.

[4] Qin, F.J. (2011) Snoop of Guarantee Limited Liability Company. The People's Forum, 12.

[5] Dou, J.W. (2014) Study on the Reform of the Legal Form of Our Company. Journal of Henan University of Economics and Law, 3. 